\title{
STUDI PASANG SURUT DI PERAIRAN INDONESIA DENGAN MENGGUNAKAN DATA SATELIT ALTIMETRI JASON-1
}

\author{
Lukman Raharjanto, Bangun Muljo Sukojo \\ Program Studi Teknik Geomatika FTSP-ITS, Kampus ITS Sukolilo, Surabaya, 60111 \\ Email : lukmanraharjanto@gmail.com
}

\begin{abstract}
Abstrak
Hampir 70\% wilayah Indonesia adalah wilayah perairan. Indonesia menyimpan potensi kekayaan sumber daya kelautan yang masih belum dieksplorasi dan dieksploitasi secara optimal, bahkan sebagian belum diketahui potensi yang sebenarnya. Hal ini mendasari akan pentingnya informasi spasial di wilayah perairan Indonesia. Fenomena naik atau turunnya permukaan laut atau SLA (Sea Level Anomaly) merupakan hal yang sering mengemuka dengan perubahan gerak relatif dari materi suatu planet, bintang, dan benda-benda angkasa lainnya yang diakibatkan aksi tarik menarik atau yang sering disebut dengan pasang surut. Saat ini telah dikembangkan sistem satelit altimetri Jason-1 yang mempunyai obyek penelitian mengamati pasang surut.

Pengolahan data biner dari satelit altimetri Jason-1 dilakukan dengan menggunakan beberapa tahapan, yaitu : konversi data, pembentukan grid, dan pemodelan serta analisa trend pasang surut. Pemantauan SLA beserta trend dan analisa pasang surut dilakukan setiap cycle dalam kurun waktu empat tahun (2008-2011).

Hasil pemantauan SLA (Sea Level Anomaly) dengan menggunakan data satelit altimetri Jason-1 mulai dari tahun 2008 sampai 2011 diperoleh terjadinya trend pasang tertinggi dan surut terendah di wilayah perairan Indonesia. Hasil penelitian menunjukkan bahwa nilai pasang tertinggi pada tahun 2008 terjadi pada cycle 236 yaitu sebesar 1,9982 m di Laut Arafuru dan nilai surut terendah terjadi pada cycle 236 yaitu sebesar -3,6954 m di Laut Arafuru. Nilai pasang tertinggi pada tahun 2009 terjadi pada cycle 290 sebesar 1,9325 m di Laut Arafuru dan nilai surut terendah terjadi pada cycle 258 sebesar -3,309 m di Laut Arafuru. Nilai pasang tertinggi pada tahun 2010 terjadi pada cycle 308 sebesar 2,1511 m di Laut Arafuru dan nilai surut terendah terjadi pada cycle 297 sebesar -2,8303 m. Nilai pasang tertinggi pada tahun 2011 terjadi pada cycle 345 sebesar 1,8402 m di Laut Arafuru dan nilai surut terendah terjadi pada cycle 348 sebesar -3,57 m. Dalam waktu empat tahun, wilayah perairan Indonesia yang mengalami nilai pasang tertinggi dan surut terendah yaitu di Laut Arafuru.
\end{abstract}

Kata Kunci : Sea Level Anomaly, Jason-1, BRAT, Trend Pasang Surut

\section{PENDAHULUAN}

\section{Latar Belakang}

Indonesia merupakan negara kepulauan yang sebagian besar wilayahnya terdiri dari daerah perairan. Perairan Indonesia menyimpan kekayaan sumber daya kelautan yang belum dieksplorasi dan dieksploitasi secara optimal. Kebutuhan akan data tentang kondisi wilayah perairan Indonesia seperti tinggi permukaan air laut sangat dibutuhkan, namun teknik untuk mendapatkan data-data tersebut masih sangat terbatas, sehingga sulit untuk mengetahui kondisi wilayah perairan di Indonesia.

Fenomena naik atau turunnya permukaan laut atau SLA (Sea Level Anomaly) merupakan hal yang sering mengemuka dengan perubahan gerak relatif dari materi suatu planet, bintang, dan benda-benda angkasa lainnya yang diakibatkan aksi tarik menarik atau yang sering disebut dengan pasang surut. Seiring dengan perkembangan teknologi, saat ini telah dikembangkan sistem satelit altimetri Jason-1 yang mempunyai obyek penelitian mengamati pasang surut laut. Sejalan dengan itu, muncul software yang khusus digunakan untuk mengolah data satelit altimetri yaitu Basic Radar Altimetry Toolbox (BRAT).

Berdasarkan alasan-alasan tersebut, penelitian ini dimaksudkan untuk melakukan analisa trend pasang surut dari data satelit Jason-1 dengan menggunakan software BRAT di perairan Indonesia. Dari hasil penelitian ini diharapkan 
dapat memberikan informasi tentang kondisi spasial perairan Indonesia.

\section{Rumusan Permasalahan}

Dari latar belakang diatas, maka perumusan masalah yang akan dilaksanakan dalam penelitian ini adalah studi pasang surut di Perairan Indonesia dari data satelit altimetri Jason-1 pada tahun 2008-2011 dengan menggunakan software BRAT dan MATLAB.

\section{Batasan Masalah/Ruang Lingkup}

Batasan permasalahan dalam penelitian ini adalah:

1. Pengamatan pasang surut di Perairan Indonesia berdasarkan data satelit altimetri Jason-1 dengan koordinat geografis $6^{\circ} \mathrm{LU}-$ $11^{\circ} \mathrm{LS}$ dan $95^{\circ} \mathrm{BT}-141^{\circ} \mathrm{BT}$.

2. Data yang digunakan adalah data satelit Altimetri Jason-1 selama 4 tahun yaitu antara tahun 2008 - 2011.

3. Hasil konversi dari software BRAT dibandingkan dengan hasil dari konversi software MATLAB.

4. Proses pemodelan dan analisa trend pasang surut dilakukan dengan menggunakan software BRAT.

\section{Tujuan}

Adapun tujuan dari tugas akhir ini adalah :

1. Memahami perbedaan proses pengolahan data dari satelit altimetri Jason-1 dengan menggunakan software yaitu BRAT dan MATLAB.

2. Mengamati trend pasang surut di Perairan Indonesia dalam selang waktu 4 tahun yaitu antara tahun 2008 -2011.

\section{Manfaat}

Adapun manfaat dari tugas akhir ini adalah untuk mendapatkan hasil analisa dari pemrosesan pasang surut yang nantinya dapat memberikan informasi mengenai trend pasang tertinggi dan surut terendah yang ada di wilayah perairan Indonesia kepada pihak - pihak yang berkepentingan guna mendukung kesalamatan pelayaran.

\section{METODOLOGI PENELITIAN}

\section{Lokasi Penelitian}

Lokasi penelitian pada tugas akhir ini adalah di perairan Indonesia yang terletak pada koordinat geografis antara $6^{\circ} \mathrm{LU}-11^{\circ} \mathrm{LS}$ dan $95^{\circ} \mathrm{BT}-141^{\circ}$ BT.

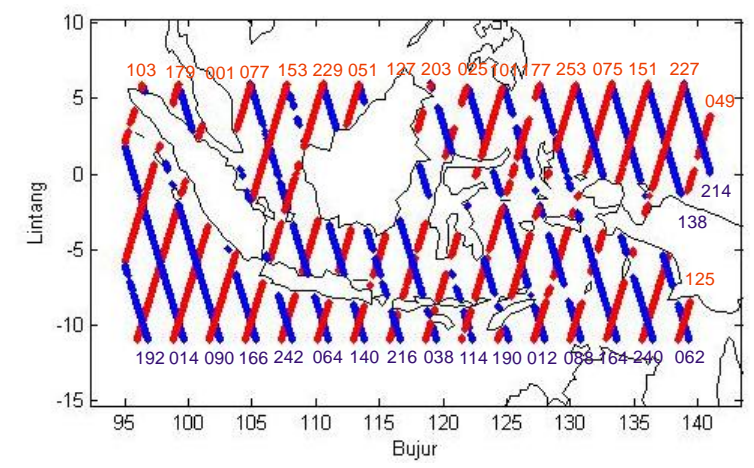

Gambar 1. Lokasi Penelitian

\section{DATA DAN PERALATAN}

- Data

1. Data hasil ukuran satelit altimetri Jason-1 dalam format biner GDR (Geophyisical Data Record) yang diproduksi oleh PODAAC dan AVISO dengan lama pengamatan empat tahun yaitu tahun 2008-2011 dari cycle 220 - 362.

2. Data hasil ukuran satelit altimetri Jason-1 dalam format ASCII (American Standard Code for Information Interchange) yang diproduksi oleh RADS (Radar Altimetry Database System).

\section{- Peralatan}

1. Perangkat Keras (Hardware)

a. Notebook Toshiba seri L745.

b. Printer Canon IP 2770.

2. Perangkat Lunak (Software)
a. BRAT untuk pengolahan dan pemodelan data satelit Jason-1.
b. MATLAB untuk membandingkan hasil pengolahan data.
c. Google Earth untuk menentukan pass dari satelit Jason-1 yang melewati Perairan Indonesia


d. Microsoft Office Word dan Excel 2010 untuk penulisan laporan.

\section{Diagram Alir}

Secara umum tahap penelitian ini dapat digambarkan sebagai berikut:

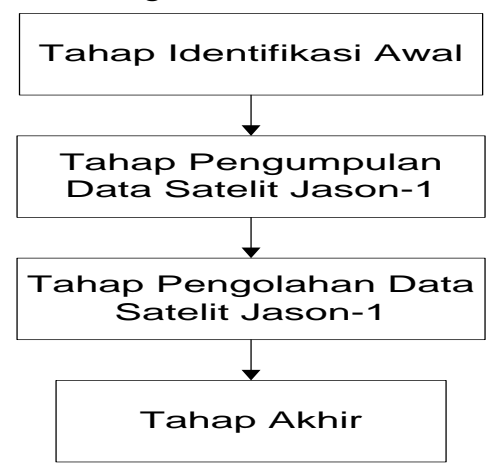

Gambar 2. Diagram Alir Penelitian

Adapun penjelasan Gambar 2. adalah sebagai berikut :

1. Tahap Identifikasi Awal

Tahap ini terdiri dari perumusan masalah, tujuan, dan studi literatur yang terkait penelitian ini.

2. Tahap Pengumpulan Data

Pada tahap ini dilakukan pengumpulan data yang berupa data mentah dari satelit Jason-1 dalam format biner dan data pendukung yang diperoleh dari RADS.

3. Tahap Pengolahan Data

Tahap pengolahan data merupakan tahapan utama yang dilakukan dalam penyelesaian tugas akhir ini. Adapun langkah-langkah pengolahan data pada penelitian ini dibagi menjadi dua tahap pengolahan, yaitu :

a. Pengolahan data dengan MATLAB.

b. Pengolahan data dengan BRAT.

4. Tahap Akhir

Hasil dari pengolahan data satelit Jason-1, pada tahap ini diberikan analisa. Analisa berupa pasang surut tertinggi dan terendah pada setiap tahun dari hasil pengolahan BRAT.

\section{Pengolahan Data}

Adapun langkah pengolahan data adalah sebagai berikut :

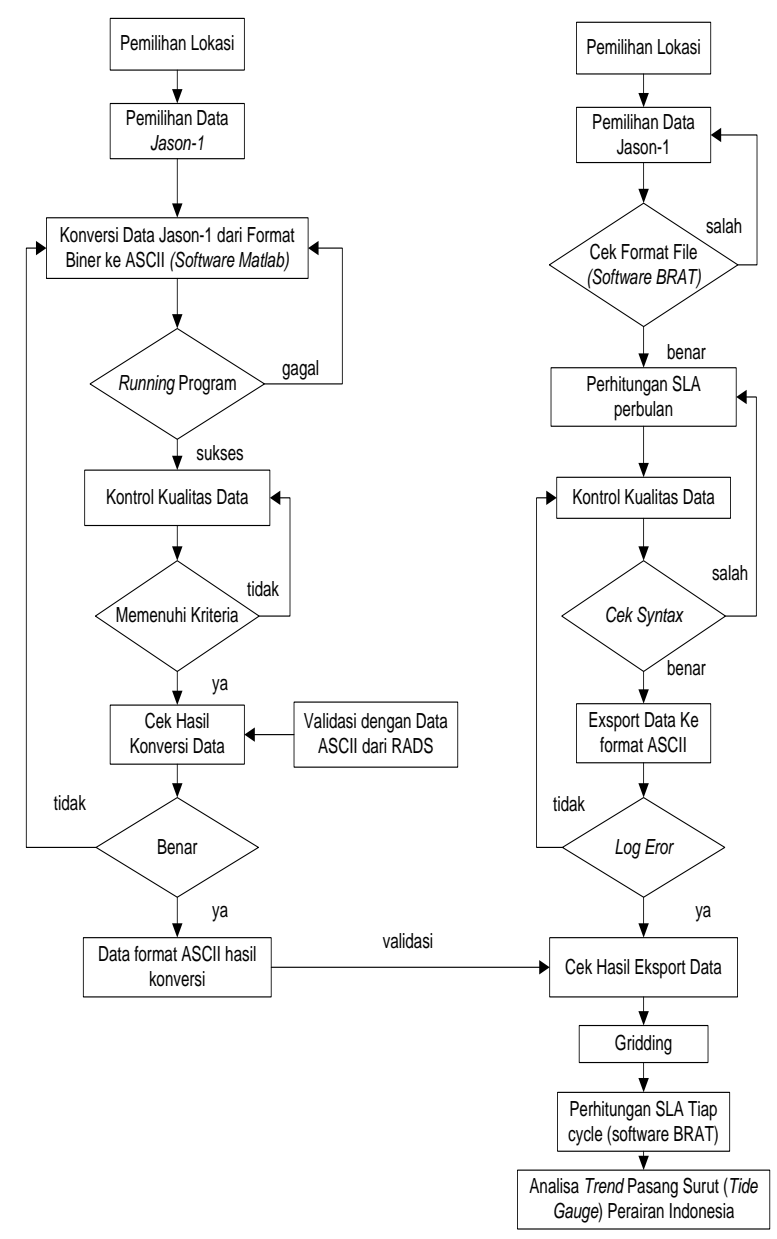

Gambar 3. Diagram Alir Pengolahan Data

Proses pengolahan data pada penelitian ini terdiri dari dua tahap, yaitu pengolahan data dengan menggunakan MATLAB dan BRAT. Adapun langkah pengolahan data dengan MATLAB adalah sebagai berikut :

1. Konversi data dilakukan untuk mengubah format biner pada data ukuran GDR menjadi format ASCII agar didapatkan parameterparameter yang dibutuhkan dalam perhitungan SLA (Sea Level Anomaly).

2. Untuk mendapatkan data yang valid, maka perlu dilakukan kontrol kualitas data. Menurut AVISO dan PODAAC (2008) kualitas data yang bagus harus sesuai dengan kriteriakriteria pada Tabel 1. 
Tabel 1. Kriteria data Jason-1

\begin{tabular}{|c|c|c|}
\hline No & Macam Data & Kriteria Data \\
\hline 1 & $\begin{array}{l}\text { Jumlah pengamatan } \\
\text { valid dalam band } \mathrm{Ku}\end{array}$ & range_numval_ku > 10 \\
\hline 2 & $\begin{array}{l}\text { RMS jarak altimeter } \\
\text { dalam band } \mathrm{Ku}\end{array}$ & $\begin{array}{c}0 \mathrm{~mm}<\text { range_rms_ku }<200 \\
\mathrm{~mm}\end{array}$ \\
\hline 3 & Altitude-Range_ku & $\begin{array}{l}-130000 \mathrm{~mm}<\text { altitude }- \\
\text { range_ku }<10000 \mathrm{~mm}\end{array}$ \\
\hline 4 & $\begin{array}{l}\text { Koreksi troposfer } \\
\text { kering }\end{array}$ & $\begin{array}{c}-2500 \mathrm{~mm}< \\
\text { model_dry_tropo_corr }<-1900 \\
\mathrm{~mm}\end{array}$ \\
\hline 5 & $\begin{array}{c}\text { Koreksi troposfer } \\
\text { basah }\end{array}$ & $\begin{array}{c}-500 \mathrm{~mm}<\text { wet } \\
\text { rad_wet_tropo_corr }<-1 \mathrm{~mm}\end{array}$ \\
\hline 6 & Koreksi ionosfer & $\begin{array}{c}-400 \mathrm{~mm}<\text { iono_corr_alt_k }<40 \\
\mathrm{~mm}\end{array}$ \\
\hline
\end{tabular}

7

Bias Elektromagnetik

(EMB)

8

Koreksi pasang surut

laut

9

Koreksi pasang surut

pembebanan

Koreksi pasang surut kutub

11

Significant Wave Height

12

Sigma Naught

13

Kecepatan angin

Square of off Nadir

14
$-500 \mathrm{~mm}<$ sea_state_bias_ku $<$

$0 \mathrm{~mm}$

$-5000 \mathrm{~mm}<$ ocean_tide_sol1 $<$

$+5000 \mathrm{~mm}$

$-1000 \mathrm{~mm}$ < solid_earth_tide <

$$
+1000 \mathrm{~mm}
$$

$-150 \mathrm{~mm}<$ pole_tide $<+150 \mathrm{~mm}$

$0 \mathrm{~mm}<\mathrm{swh} \_\mathrm{ku}<11000 \mathrm{~mm}$

$7 \mathrm{~dB}<$ sig0_ku $<30 \mathrm{~dB}$

$0 \mathrm{~m} / \mathrm{s}<$ altimeter wind speed $<$

$$
30 \mathrm{~m} / \mathrm{s}
$$

$$
-0.2 \operatorname{deg} 2<
$$

off_nadir_angle_ku_wvf $<0.16$

deg2
Angle from

Waveforms
3. Menghitung Sea Level Anomaly (SLA) Sea Level Anomaly (SLA) adalah fenomena naik atau turunnya permukaan laut. Perubahan permukaan laut ini Dihitung dari permukaan ellipsoid, dan telah dikurangi dengan nilai Mean Sea Surface. Perhitungan SLA :

$$
\operatorname{SLA}=H-\rho-\varepsilon
$$

$\varepsilon=\varepsilon^{i o}+\varepsilon^{t r o(w e t)}+\varepsilon^{t r o(d r y)}+\varepsilon_{S S B}+\varepsilon^{o t}+\varepsilon^{e t}+\varepsilon^{p t}+\varepsilon^{i B}+\varepsilon^{L}+\ldots$

$\varepsilon_{G H / M S S}$

dimana :

$H \quad=$ tinggi satelit di atas elipsoid $(\mathrm{m})$

$\rho=\quad=$ tinggi satelit altimeter di atas muka

laut (m)

$\varepsilon \quad=$ total koreksi $(\mathrm{mm})$

$\varepsilon^{i o} \quad=$ koreksi ionosfer $(\mathrm{mm})$

$\varepsilon^{\text {tro(wet })}=$ koreksi troposfer basah $(\mathrm{mm})$

$\varepsilon^{\text {tro }(\text { dry })}=$ koreksi troposfer kering $(\mathrm{mm})$

$\varepsilon^{\text {ot }} \quad=$ koreksi efek pasang surut laut $(\mathrm{mm})$

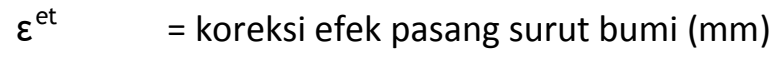

$\varepsilon^{\text {et }} \quad=$ koreksi efek pasang surut kutub $(\mathrm{mm})$

$\varepsilon^{\mathrm{iB}} \quad=$ koreksi efek inverse tekanan udara $(\mathrm{mm})$

$\varepsilon^{\mathrm{L}} \quad=$ koreksi efek ocean loading $(\mathrm{mm})$

$\varepsilon_{S S B} \quad=$ koreksi gelombang permukaan $(\mathrm{mm})$

$\varepsilon_{G H / M S S}=$ reduksi tinggi geoid atau mean sea surface $(\mathrm{mm})$

Setelah diperoleh hasil pengolahan dari MATLAB, selanjutnya, melakukan pengolahan data dengan BRAT. Adapun langkah-langkah pengolahannya adalah sebagai berikut.

1. Penentuan lokasi penelitian Lokasi penelitian dalam penelitian ini adalah wilayah perairan Indonesia.

2. Pemilihan data

Pemilihan data yang sesuai dengan lokasi penelitian ini pada BRAT dilakukan pada ruang Datasets.

3. Check format file

Pengecekan ini bertujuan untuk mengetahui apakah data-data yang terdapat dalam sebuah datasets memiliki format yang sama atau tidak. 
4. Perhitungan nilai SLA perbulan dilakukan dengan persamaan (1) dan (2). Perhitungan ini bertujuan untuk mengurangi noise.

5. Kontrol kualitas data

Untuk mendapatkan data yang valid, maka perlu dilakukan kontrol kualitas data. Menurut AVISO dan PODAAC (2008) kualitas data yang bagus harus sesuai dengan kriteriakriteria pada Tabel 1.

6. Check Syntax

Untuk mengetahui apakah proses penulisan rumus yang dilakukan terdapat kesalahan atau tidak, maka perlu dilakukan pengecekan syntax.

7. Simpan hasil dalam format ASCII

8. Selanjutnya pada ruang log dilihat apakah dalam pengeksportan data terjadi kesalahan (error) atau tidak. Apabila log error maka perlu dilakukan pengecekan kembali kontrol kualitas datanya. Pada BRAT dilakukan pada ruang log.

9. Gridding

Sebelum diadakan analisa dilakukan proses gridding. Dimana proses ini mampu menghasilkan nilai interpolasi grid yang baik pada titik estimasi yang ada pada lingkup daerah pemodelan.

10. Perhitungan SLA tiap Cycle

Dilakukan perhitungan SLA tiap cycle pada software BRAT dengan menggunakan hasil perhitungan SLA (Sea Level Anomaly) perbulan. Hasil dari SLA perbulan dimasukkan pada kriteria data software BRAT.

\section{HASIL DAN PEMBAHASAN}

\section{Data dengan MATLAB \\ Konversi Data}

Tahap pertama yang dilakukan dalam pemrosesan menggunakan MATLAB adalah konversi data dari format biner (GDR Jason-1) menjadi data format ASCII. Konversi ini bertujuan untuk mendapatkan parameter-parameter yang dibutuhkan dalam menghitung SLA (Sea Level Anomaly).

Setelah melakukan konversi data, selanjutnya melakukan kontrol kualitas data sesuai dengan Tabel 1. Data yang sesuai dengan kriteria akan dibaca sebagai data ASCII, sedangkan data yang tidak sesuai dengan kriteria akan dibaca sebagai NaN (Not as Number).

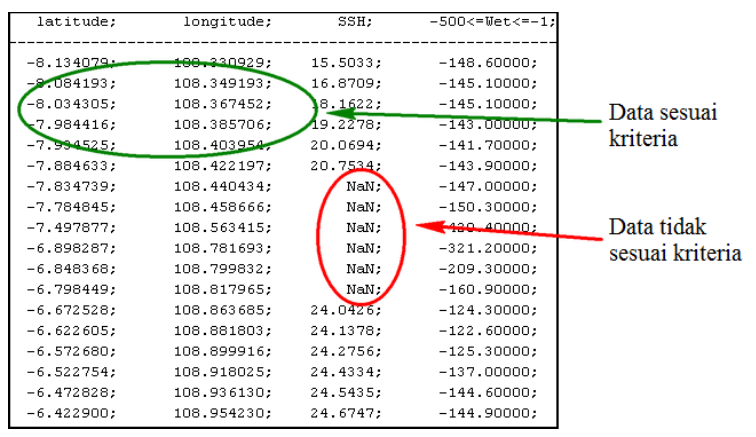

Gambar 4. Hasil Kontrol Kualitas Data

\section{Validasi Hasil Konversi MATLAB}

Proses validasi ini dilakukan dengan mengoverlay-kan gambar lintasan satelit Jason-1 yang ada pada data RADS dengan lintasan yang ada pada data ASCII hasil konversi MATLAB.

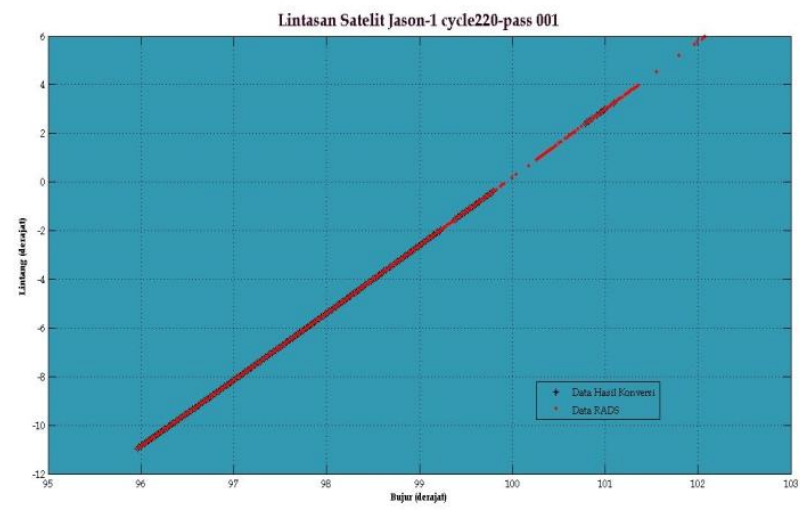

Gambar 5. Validasi Hasil Konversi MATLAB dan RADS Cycle 220 Pass 001

Berdasarkan Gambar 5. diketahui bahwa lintasan hasil konversi MATLAB dan data RADS saling bertampalan, maka dapat disimpulkan bahwa hasil konversi data dari MATLAB memiliki hasil yang valid.

\section{Pemrosesan Data dengan BRAT Konversi Data}

Data format biner dari satelit Jason-1 terlebih dahulu dikonversi menjadi format ASCII dengan menggunakan software BRAT. Adapun contoh hasil konversinya adalah sebagai berikut : 
Tabel 2. Hasil Konversi data biner dengan BRAT

\begin{tabular}{ccc}
\hline Lintang $\left(^{\circ}\right)$ & Bujur $\left(^{\circ}\right)$ & SLA $(\mathrm{m})$ \\
\hline-10.961281 & 95.956468 & 0.3078 \\
-10.911488 & 95.975104 & 0.331 \\
-10.861692 & 95.993733 & 0.3042 \\
-10.811895 & 96.012354 & 0.2975 \\
-10.762096 & 96.030968 & 0.3718 \\
-10.712295 & 96.049574 & 0.3503 \\
-10.662492 & 96.068173 & 0.3736 \\
-10.612687 & 96.086765 & 0.3226 \\
-10.562881 & 96.105349 & 0.3744 \\
-10.513072 & 96.123926 & 0.3521 \\
\hline
\end{tabular}

\section{Validasi Hasil Konversi BRAT}

Uji validasi data hasil konversi ini dilakukan dengan melakukan overlay hasil konversi nilai SLA dari BRAT dan MATLAB.

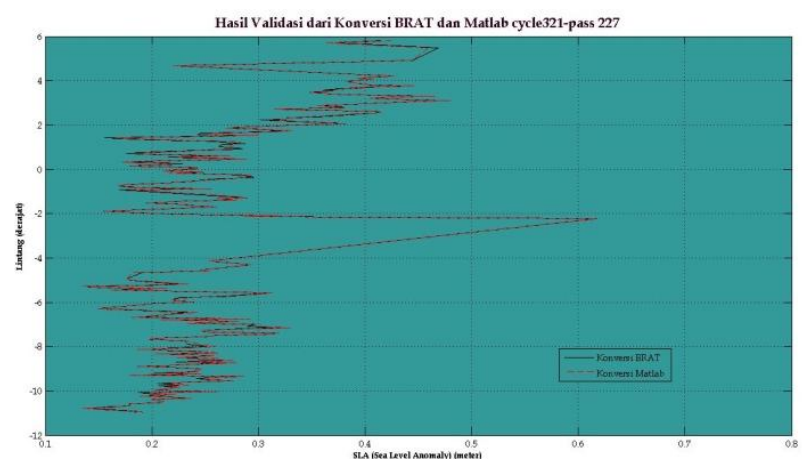

Gambar 6. Validasi Nilai SLA Hasil Konversi MATLAB dan BRAT Cycle 321 Pass 227

Berdasarkan Gambar 6. diketahui bahwa nilai SLA hasil konversi BRAT dan MATLAB saling bertampalan, maka dapat disimpulkan bahwa hasil konversi data dari BRAT memiliki hasil yang valid.

\section{Pengeplotan Grafik Dan Visualisasi SLA dengan BRAT}

Pada software BRAT data yang sudah diexport /dikonversi dilakukan pengeplotan yakni pengeplotan grafik hasil konversi /export data dan pengeplotan visualisasi hasil SLA tiap bulan. Hasil nilai SLA tiap bulan perlu dilakukan untuk dapat melakukan analisa tide gauge (pasang surut) dari nilai SLA untuk tiap musim serta untuk mengurangi noise. Proses pengeplotan pada software BRAT ini sebelumnya dilakukan perhitungan (execute) nilai SLA tiap bulan terlebih dahulu pada ruang operations. Kemudian untuk menampilkan hasil SLA dalam bentuk grafik dan gambar visualisasinya dapat dilihat diruang views. Maka diperoleh hasil seperti berikut

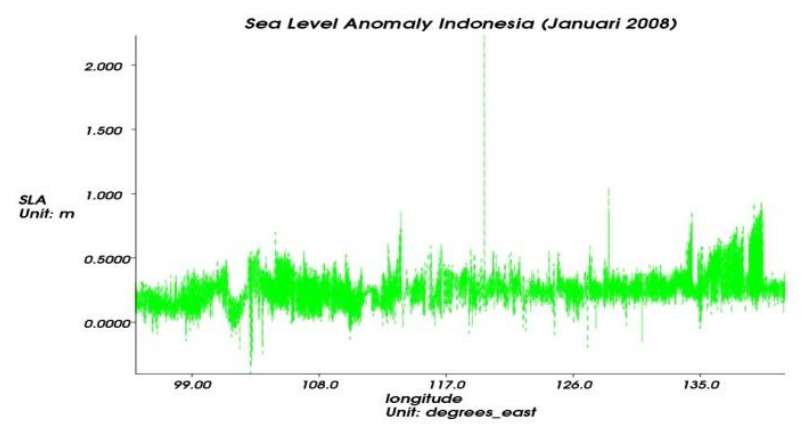

Gambar 7. Hasil Pengeplotan Grafik SLA pada Software BRAT Januari 2008

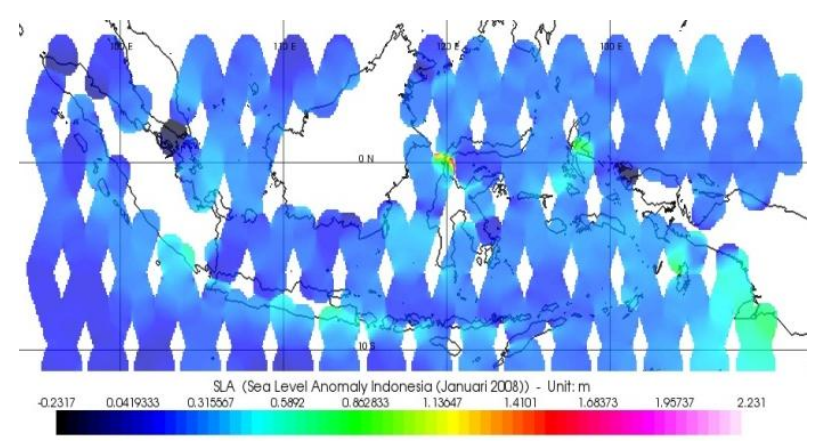

Gambar 8. Hasil Pengeplotan Visualisasi SLA pada Software BRAT Januari 2008

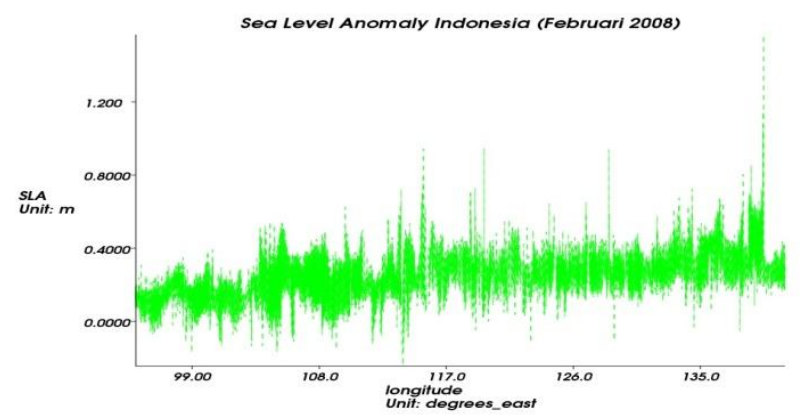

Gambar 9. Hasil Pengeplotan Grafik SLA pada Software BRAT Februari 2008 


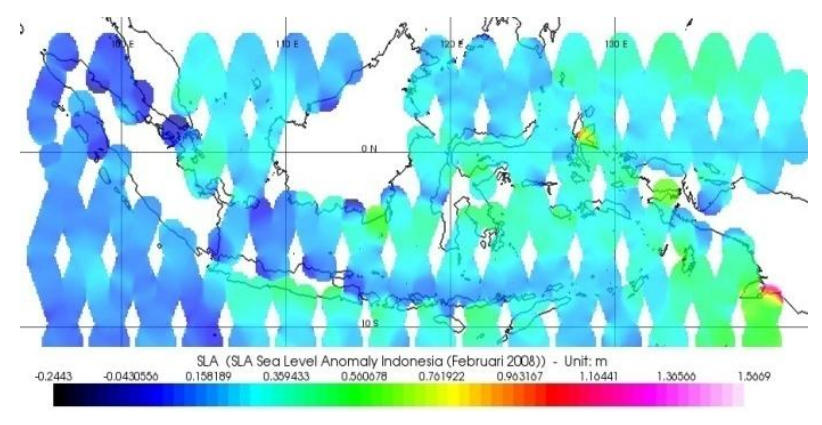

Gambar 10. Hasil Pengeplotan Visualisasi SLA pada Software BRAT Februari 2008

\section{Gridding SLA dengan MATLAB}

Proses gridding nilai SLA dilakukan untuk memperoleh gambaran visual nilai SLA di perairan Indonesia, sehingga dengan jelas dapat melihat fenomena - fenomena tertentu salah satunya tide gauge (pasang surut). Griding dilakukan dengan menggunakan inverse distance weighted (IDW) yaitu suatu metode interpolasi yang dapat digunakan untuk menginterpolasi suatu nilai secara spasial dari nilai sekitarnya dengan melakukan pembebanan (Kosasih Prijatna,2006).

Dari perhitungan interpolasi maka diperoleh hasil dari gridding nilai SLA di wilayah perairan Indonesia selama perbulan dalam kurun waktu 4 tahun. Data nilai SLA (Sea Level Anomaly) tersebut kemudian diplot dengan menggunakan software MATLAB seperti pada gambar berikut :

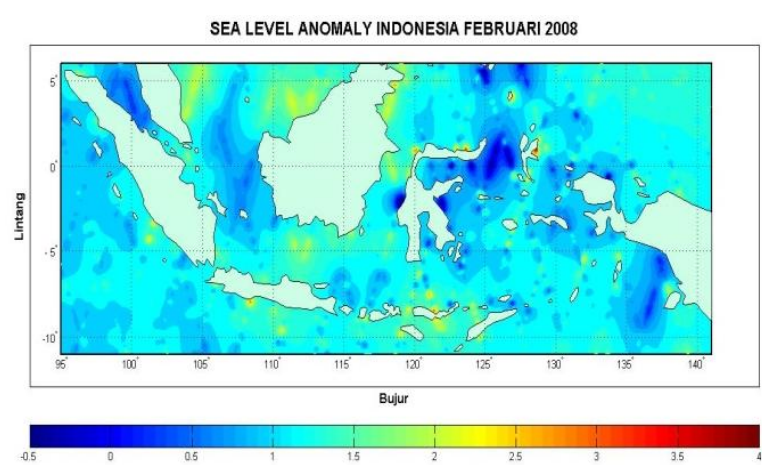

Gambar 11. Sea Level Anomaly Perairan Indonesia Hasil Gridding bulan Januari 2008

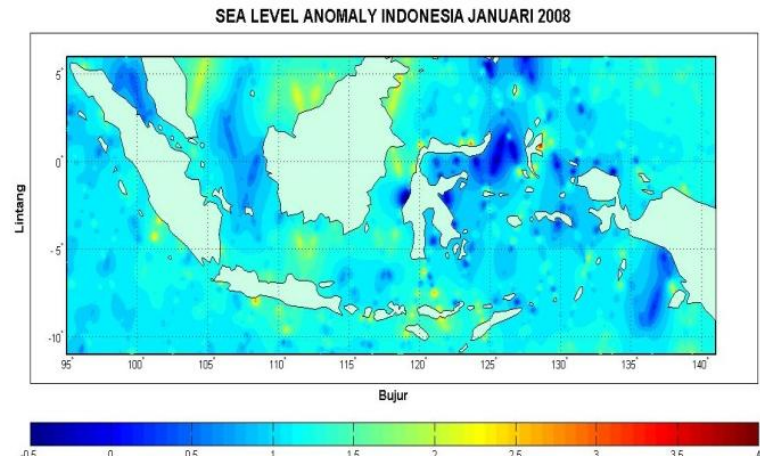

Gambar 12. Sea Level Anomaly Perairan Indonesia Hasil Gridding bulan Februari 2008

\section{Analisa}

\section{Analisa Pengolahan Data}

Setelah melakukan beberapa tahap pengolahan data dengan menggunakan BRAT dan MATLAB, dapat diketahui beberapa perbedaan antara BRAT dan MATLAB. Adapun perbedaan tersebut dapat dijelaskan pada Tabel 3. berikut.

Tabel 3. Perbedaan Pengolahan Data dengan menggunakan Software BRAT dan MATLAB

\begin{tabular}{ccc}
\hline Parameter & $\begin{array}{c}\text { Pengolahan } \\
\text { dengan BRAT }\end{array}$ & $\begin{array}{c}\text { Pengolahan } \\
\text { dengan MATLAB }\end{array}$ \\
\hline $\begin{array}{c}\text { Proses Konversi } \\
\text { Data } \\
\text { Hasil Konversi } \\
\text { Data }\end{array}$ & Lebih Mudah & Tidak Mudah \\
Visualisasi & Kurang Menarik & Lebih Menarik \\
Hasil & Ditampalkan & $\begin{array}{c}\text { Ditampalkan } \\
\text { Diatas Hasil }\end{array}$ \\
$\begin{array}{c}\text { Pengeplotan } \\
\text { Griddding }\end{array}$ & Tidak Dilakukan & $\begin{array}{c}\text { Pengolahan Data } \\
\text { Lintang dan } \\
\text { Bujur }\end{array}$ \\
& $\begin{array}{c}\text { Tidak Dapat } \\
\text { Ditampilkan }\end{array}$ & Dilakukan \\
& & Denampilkan \\
\hline
\end{tabular}

Proses pengolahan data dengan BRAT dan MATLAB juga memiliki beberapa persamaan. Adapun persamaanya adalah sebagai berikut:

1. Nilai SLA dan parameter-parameter yang dihasilkan oleh BRAT dan MATLAB memiliki nilai yang sama.

2. Hasil pemodelan antara BRAT dan MATLAB memiliki pola yang hampir sama. 
3. Hasil konversi jumlahnya tidak ada perbedaan.

\section{Trend Pasang Surut dan Pengeplotan pada BRAT}

Setelah data SLA (Sea Level Anomaly) yang telah digriding di plot pada software MATLAB, dilakukan perhitungan pasang surut (tide gauge) pada software BRAT di ruang Operations dengan menggunakan rumus Tide Effects (AVISO, 2006). Selanjutnya nilai SLA yang telah dihitung secara perbulan (monthly) dimasukkan dalam kriteria data pada ruang Operations.

Perhitungan pasang surut ini dilakukan setiap per cycle (satu kali satelit Jason-1 mengukur seluruh bumi) selama empat tahun, yang bertujuan untuk dapat menganalisis setiap 10 hari laut yang mengalami pasang surut dengan menggunakan data satelit altimetri Jason-1. Data yang digunakan pada penelitian ini tidak semuanya diproses, karena ada beberapa pass pada beberapa cycle yang hilang. Kemudian hasil pengolahan pasang surut dilakukan pengeplotan grafik hasil perhitungan dan pengeplotan visualisasi hasil pasang surut tiap cycle di ruang Views. Adapun beberapa contoh visualisasi dan grafik pengeplotan pasang surut per cycle sebagai berikut :

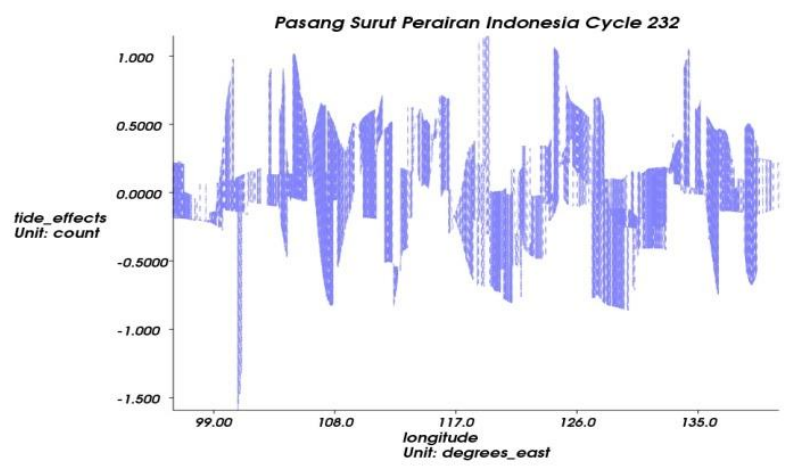

Gambar 13. Hasil Pengeplotan Grafik Pasang Surut dengan Software BRAT pada cycle 232

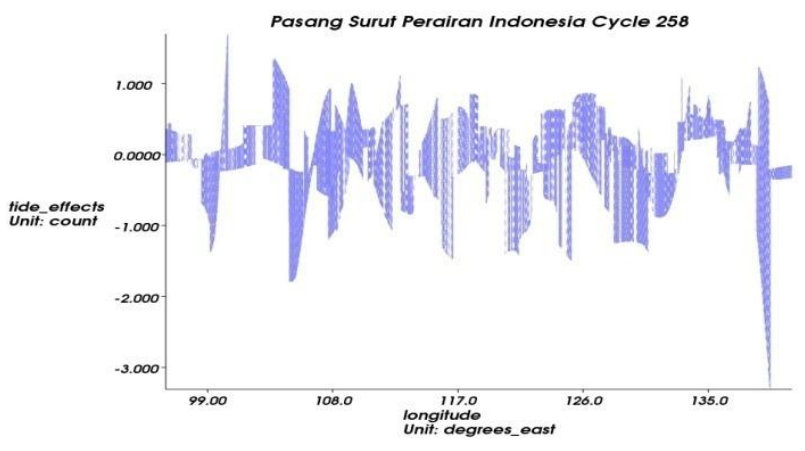

Gambar 14. Hasil Pengeplotan Visualisasi Pasang Surut dengan Software BRAT pada cycle 232

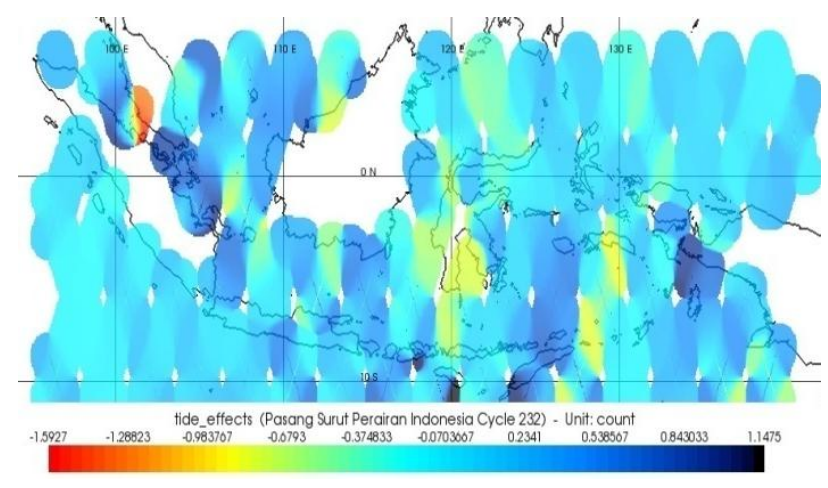

Gambar 15. Hasil Pengeplotan Grafik Pasang Surut dengan Software BRAT pada cycle 258

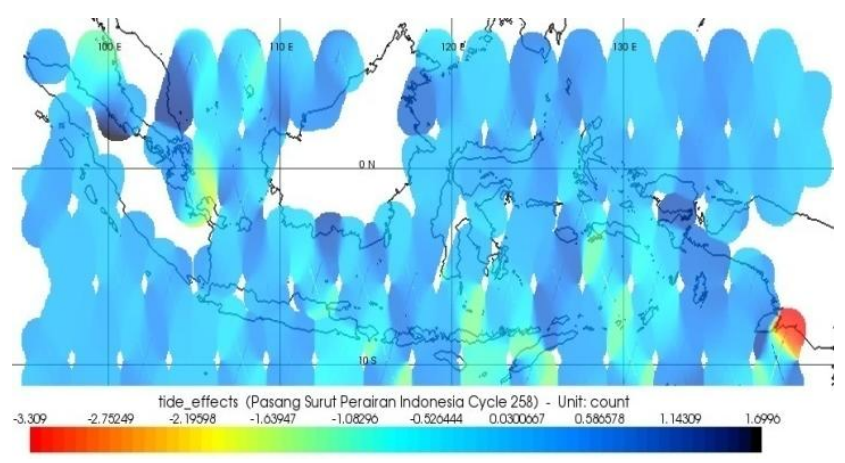

Gambar 16. Hasil Pengeplotan Visualisasi Pasang Surut dengan Software BRAT pada cycle 258

\section{Analisa Trend Pasang Surut}

Setelah didapatkan nilai pasang surut dari BRAT, selanjutnya dilakukan analisa dari pasang surut perairan Indonesia. Adapun hasil nilai pasang surut terendah dan tertinggi pada setiap tahunnya dapat dilihat pada Gambar 16. 


\begin{tabular}{|c|c|c|c|c|c|c|c|c|}
\hline \multirow{2}{*}{ Tahun } & \multicolumn{4}{|c|}{ Pasang Surut Terendah } & \multicolumn{4}{c|}{ Pasang Surut Tertinggi } \\
\cline { 2 - 10 } & Cycle & Lintang $\left({ }^{\circ}\right)$ & Bujur $\left({ }^{\circ}\right)$ & PS $(\mathrm{m})$ & Cycle & Lintang $\left({ }^{\circ}\right)$ & Bujur $\left({ }^{\circ}\right)$ & PS(m) \\
\hline 2008 & 236 & -7.345017 & 138.001622 & -3.6954 & 236 & -5.577877 & 137.617822 & 1.9982 \\
\hline 2009 & 258 & -8.277743 & 139.469045 & -3.309 & 290 & -7.106693 & 138.481049 & 1.9325 \\
\hline 2010 & 297 & -7.075582 & 138.489362 & -2.8303 & 308 & -7.035243 & 138.501992 & 2.1511 \\
\hline 2011 & 348 & -7.025788 & 138.505559 & -3.57 & 345 & -8.563419 & 137.024414 & 1.2596 \\
\hline
\end{tabular}

Gambar 17. Nilai Pasang Surut Terendah dan Tertinggi

Berdasarkan Gambar 17. dapat diambil kesimpulan bahwa pada tahun 2008, nilai pasang surut terendah terjadi pada Cycle 236 sebesar 3,6954 m pada tanggal 24 Juni -3 Juli 2008 di Laut Arafura dan nilai pasang surut tertinggi terjadi pada Cycle 236 sebesar 1,9982 m pada tanggal 24 Juni - 3 Juli 2008 di Laut Arafura. Pada tahun 2009, nilai pasang surut terendah terjadi pada Cycle 258 sebesar $-3,309$ m pada tanggal 20 Januari - 29 Januari 2009 di Laut Arafura dan nilai pasang surut tertinggi terjadi pada Cycle 290 sebesar $1,9325 \mathrm{~m}$ pada tanggal 6 Desember -15 Desember 2009 di Laut Arafura. Pada tahun 2010, nilai pasang surut terendah terjadi pada Cycle 297 sebesar $-2,8303 \mathrm{~m}$ pada tanggal 14 Februari -23 Februari 2010 di Laut Arafura dan nilai pasang surut tertinggi terjadi pada Cycle 308 sebesar 2,1511 m pada tanggal 4 Juni - 13 Juni 2010 di Laut Arafura. Pada tahun 2011, nilai pasang surut terendah terjadi pada Cycle 348 sebesar $-3,57 \mathrm{~m}$ pada tanggal 29 Juli - 7 Agustus 2011 di Laut Arafura dan nilai pasang surut tertinggi terjadi pada Cycle 345 sebesar $1,8402 \mathrm{~m}$ pada tanggal 29 Juni - 8 Juli 2011 di Laut Arafura.

Dari hasil analisa trend pasang surut dengan menggunakan data satelit altimetri Jason-1 di Perairan Indonesia terdapat beberapa persamaan lokasi pasang tertinggi dan surut terendah antara tahun 2008 - 2011 dan cycle yang sama pada tahun 2008 yang terjadi pasang tertinggi dan surut terendah. Persamaan lokasi yang terjadi pasang tertinggi dan surut terendah pada tahun 2008 - 2011 yaitu terjadi di Laut Arafura. Hal ini disebabkan terjadi proses upwelling terutama pada musim timur, dimana massa air dari kedalaman tertentu dengan temperatur rendah, salinitas tinggi dan kaya akan zat hara naik ke permukaan, juga pengaruh desakan massa air dari Laut Banda yang mendorong pembentukan lapisan massa air bersalinitas relatif tinggi sehingga memungkinkan terjadinya percampuran antara massa air dengan Laut Banda dan Samudera Pasifik bagian selatan. Sedangkan, untuk cycle yang sama pada tahun 2008 yang terjadi pasang tertinggi dan surut terendah yaitu cycle 236 pada tanggal 24 Juni -3 Juli 2008.

\section{KESIMPULAN dan SARAN}

\section{Kesimpulan}

Dari hasil penelitian dapat disimpulkan bahwa:

1. Proses konversi data dengan menggunakan software BRAT lebih mudah daripada menggunakan software MATLAB, namun data yang dihasilkan dengan menggunakan software MATLAB lebih banyak daripada menggunakan software BRAT.

2. Pada proses gridding (pengisian kekosongan data) hanya bisa dilakukan dengan software MATLAB dan untuk software BRAT tidak bisa dilakukan proses gridding.

3. Pola pemodelan pada pengeplotan menggunakan software BRAT dan MATLAB memiliki pola SLA (Sea Level Anomaly) yang hampir sama, namun hasil pengeplotan menggunakan software BRAT kurang maksimal dibandingkan software MATLAB.

4. Nilai pasang surut tertinggi pada tahun 2008 terjadi pada Cycle 236 dengan koordinat geografis lintang $-5^{\circ} 34^{\prime} 41,3^{\prime \prime}$ dan bujur $137^{\circ} 37^{\prime} 5,31^{\prime \prime}$ sebesar $1,998 \mathrm{~m}$ yaitu di Laut Arafura dan pasang surut terendah terjadi pada Cycle 236 dengan koordinat geografis lintang $-7^{\circ} 20^{\prime} 43,56^{\prime \prime}$ dan bujur $138^{\circ} 0^{\prime} 6,34^{\prime \prime}$ sebesar $-3,695 \mathrm{~m}$ yaitu di Laut Arafura. Nilai pasang surut tertinggi pada tahun 2009 terjadi pada Cycle 290 dengan koordinat geografis lintang $-7^{\circ} 6^{\prime} 25,89^{\prime \prime}$ dan bujur $138^{\circ} 28^{\prime} 43,21^{\prime \prime}$ sebesar $1,932 \mathrm{~m}$ yaitu di Laut Arafura dan pasang surut terendah terjadi pada Cycle 258 dengan koordinat geografis lintang $-8^{\circ} 16^{\prime} 39,78^{\prime \prime}$ dan bujur $139^{\circ} 28^{\prime} 9,59^{\prime \prime}$ sebesar $-3,309 \mathrm{~m}$ yaitu di Laut Arafura. Nilai pasang surut tertinggi pada tahun 2010 terjadi pada Cycle 308 dengan koordinat geografis lintang $-7^{\circ} 2^{\prime} 7,32^{\prime \prime}$ dan bujur $138^{\circ} 30^{\prime} 7,66^{\prime \prime}$ sebesar $2,151 \mathrm{~m}$ yaitu di Laut Arafura dan pasang surut terendah terjadi pada Cycle 297 dengan koordinat geografis lintang $-7^{\circ} 4^{\prime} 32,1^{\prime \prime}$ dan bujur $138^{\circ} 29^{\prime} 22^{\prime \prime}$ 
sebesar $-2,830 \mathrm{~m}$ yaitu di Laut Arafura. Nilai pasang surut tertinggi pada tahun 2011 terjadi pada Cycle 345 dengan koordinat geografis lintang $-8^{\circ} 11^{\prime} 28,26^{\prime \prime}$ dan bujur $139^{\circ} 43^{\prime} 2,93^{\prime \prime}$ sebesar adalah $1,840 \mathrm{~m}$ yaitu di Laut Arafura dan pasang surut terendah terjadi pada Cycle 348 dengan koordinat geografis lintang $-7^{\circ} 1^{\prime} 32,8^{\prime \prime}$ dan bujur $138^{\circ} 30^{\prime} 20^{\prime \prime}$ sebesar adalah $-3,57 \mathrm{~m}$ yaitu di Laut Arafura.

5. Selama empat tahun, wilayah Perairan Indonesia yang memiliki nilai pasang surut tertinggi dan terendah yaitu di Laut Arafura.

\section{Saran}

1. Perlunya diadakan studi lebih lanjut mengenai perubahan SLA (Sea Level Anomaly) di wilayah perairan Indonesia dari data satelit altimetri yang terbaru mengingat hampir sebagian populasi penduduk Indonesia tersebar di wilayah pesisir.

2. Diperlukan suatu data multi satelit (3 satelit) untuk mengetahui hasil yang lebih valid.

\section{DAFTAR PUSTAKA}

Abidin, H.Z. 2001. Geodesi Satelit. Jakarta: Pradnya Paramita.

Arief, A.R. 2009. Pemodelan Topografi Muka Air Laut (Sea Surface Topography) Dengan Menggunakan Data Satelit Altimetri Topex/Poseidon; Studi Kasus Samudera Indonesia. Surabaya : Prodi Teknik Geomatika-ITS.

$\begin{array}{crr}\text { AVISO, 2006. Aviso User } \\ \text { Handbook } & \text { Sea } & \text { Level }\end{array}$
Anomalies.<URL:http://podaac.jpl.nasa.gov/cdrom /mgdrb/Document/HTML/uhsec07.htm>. Dikunjungi pada tanggal 15 Februari 2012, jam 21.00.

AVISO dan PODAAC. 2003. User Handbook IGDR and GDR Products edition 2.0. NASA dan CNES.

Away, G.A. 2006. The Shortcut of Matlab Programming. Jakarta: Penerbit Informatika.
Benada, J.Robert. 2007. Physical Oceanography Distributed Active Archive Center PO.DAAC Merged GDR (TOPEX/Poseidon).<URL:http://podaac.jpl.nasa.go v/cdrom/mgdrb/Document/HTML/uhsec07.htm>. Dikunjungi pada tanggal 13 Februari 2012, jam 22.00

Benveniste, J. dkk. 2009. Radar Altimetry Tutorial.

CNES dan ESA.2006. Basic Radar Altimetry Toolbox v 2.0.0 User Manual.Esa:CNES

Destin, L. 2008. Analisa Sea Level Variability Dari Data Satelit Altimetri TOPEX/Poseidon. Surabaya: Prodi Teknik Geomatika-ITS.

Djunarsjah,E.2005.PasutLaut.<URL:http://pasut/leastsq uare.htm> Dikunjungi pada tanggal 15 Februari 2012, jam 22.00

ESA dan CNES. 2009. Basic Radar Altimetry Toolbox v2.0 User Manual.

Gunadi. 1999. Pemrosesan Topografi Muka Air Laut Dari Data Satelit Altimetri TOPEX/Poseidon. Bandung: Jurusan Teknik Geodesi Fakultas Teknik Sipil dan Perencanaan-ITB.

Handoko, E.Y. 2004. Satelit Altimetri dan Aplikasinya dalam Bidang Kelautan. Pertemuan Ilmiah Tahunan (PIT) 1. Surabaya: Teknik Geodesi ITS.

Nadar,SW. 2009. Pemrosesan Data Satelit Altimetri Dan Tide Gauge untuk Pengamatan Sea Level Change; Studi Kasus Samudera Indonesia. Surabaya : Tugas Akhir Prodi Teknik GeomatikaITS.

Mayasari, O.S. 2009. Analisa Sea Level Rise Dari Data Satelit Altimetri Topex/Poseidon Dan Data Sea Surface Temperature. Surabaya : Tugas Akhir Prodi Teknik Geomatika-ITS

Poerbandono dan Eka Djunarsjah. 2005. Survei Hidrografi. Bandung: Refika Aditama.

Prijatna, Kosasih. 2007. Pemantauan Anomaly Tinggi Muka Laut Perairan Indonesia. Bandung: Jurusan Teknik Geodesi - ITB.

RADS. 2012. Radar Altimetry Data Aqcuisition. <URL: http://rads.tudelft.nl/rads/data/ submitradsrequest.cgi>. Dikunjungi pada tanggal 13 Januari 2012, jam 14.00

Rhamo, Arkadia. 2009. Pemodelan Topografi Muka Air Laut (Sea Surface Topography) Perairan Indonesia Dari Data Satelit Altimetri Jason-1. Surabaya : Tugas Akhir Prodi Teknik Geomatika-ITS 